\title{
Disclosure of Environmental Violations and the Stock Market in the Republic of Korea
}

\author{
SUSMITA DASGUPTA \\ Development Research Group, Infrastructure and Environment, The World Bank, \\ Washington, DC, USA \\ JONG HO HONG \\ College of Economics and Finance, Hanyang University, Seoul, Korea \\ BENOIT LAPLANTE \\ Independent Consultant, Montreal, Canada \\ NLANDU MAMINGI \\ The University of the West Indies, Bridgetown, Barbados
}

\begin{abstract}
Summary. For almost 20 years, the Ministry of Environment of the Republic of Korea has published on a monthly basis a list of enterprises which fail to comply with national environmental laws and regulations. In this paper, we examine the reaction of investors to the publication of these lists, and show that enterprises appearing on these lists have experienced a significant decline in their market valuation.
\end{abstract}

Key words - Environmental violations, public disclosure, stock market, Korea.

World Bank Policy Research Working Paper 3344, June 2004

The Policy Research Working Paper Series disseminates the findings of work in progress to encourage the exchange of ideas about development issues. An objective of the series is to get the findings out quickly, even if the presentations are less than fully polished. The papers carry the names of the authors and should be cited accordingly. The findings, interpretations, and conclusions expressed in this paper are entirely those of the authors. They do not necessarily represent the view of the World Bank, its Executive Directors, or the countries they represent. Policy Research Working Papers are available online at http://econ.worldbank.org.

Correspondence should be addressed to: Susmita Dasgupta, MC2-205, World Bank, 1818 H Street, NW, Washington, DC 20433, sdasgupta@worldbank.org. 


\section{Acknowledgments}

We express our sincere thanks to Mr. Jongsoo Yoon, General Director of Public Affairs at the Ministry of Environment of Korea, for his support with the data collection process. We would also like to thank Il Hwan Ahn, Dae Hee Kim, and Jeong Kyu Yoon at the graduate school of Hanyang University for their research assistance. Finally, we extend our most sincere thanks to Ms. Annette Green for her assistance. 


\section{Introduction}

It is often said that firms in developing countries do not have incentives to invest in pollution control effort because of weak implementation of environmental regulations: the cost of complying with the regulation exceed expected benefits resulting from a reduction in expected penalty. However, this argument assumes that the environmental regulator is the only agent that can effectively penalize firms lacking compliance. Recent research indicates that local communities may exercise considerable leverage to pressure firms to improve their environmental performance. ${ }^{1}$ The argument also ignores that capital markets may react negatively to the announcement of adverse environmental incidents (such as violation of permits, spills, court actions, complaints, etc.) or positively to the announcement of superior environmental performance. Hence, when accounting solely for regulators' fines and penalties and ignoring the pressure that communities and markets may bear, the expected costs associated with a poor environmental performance may be significantly under-estimated. The inability of formal institutions especially in developing countries to provide incentives for pollution control effort via the traditional channel of fines and penalties may not be as serious an impediment to pollution control as is generally argued: Communities and capital markets, if properly informed, may in specific circumstances provide appropriate incentives.

A limited number of papers have analyzed the reaction of capital markets to environmental news in Canada and the United States. These studies have generally shown that firms suffer from a decline in market values following the announcement of

\footnotetext{
1 See Afsah et al. (1996), Blackman et al. (1998), and Pargal and Wheeler (1996).
} 
adverse environmental news. ${ }^{2}$ The impact of firm-specific environmental news on market value may work its way through various channels: a high level of pollution intensity may signal to investors the inefficiency of the firm's production process; it may invite stricter scrutiny by environmental groups and/or facility neighbours; it may result in the loss of reputation, goodwill, etc. On the other hand, the announcement of a good environmental performance or of the investment in cleaner technologies may have the opposite effect: lesser scrutiny by regulators and communities (including the financial community), and greater access to international markets among other benefits. ${ }^{3}$

Studies of this nature in developing countries have been very limited in numbers. In a recent paper, Dasgupta et al. (2001) have shown that capital markets in Argentina, Chile, Mexico, and the Philippines do react negatively (decrease in firms' value) to citizens' complaints targeted at specific firms, and positively to the announcement of rewards and recognition of superior environmental performance. These results suggest that environmental regulators in developing countries may explicitly harness those market forces by introducing structured programs of information release on firms' environmental performance, and empower communities and stakeholders through environmental education programs.

Numerous countries, both developing and developed have in fact implemented such programs. An increasing number of environmental regulators around the world have

\footnotetext{
${ }^{2}$ In the United States, these studies include analyses of the reaction of capital markets to releases of the Toxics Release Inventory (Hamilton (1995), and Konar and Cohen (1997)). Lanoie and Laplante (1994) analyze the reaction of capital markets to environmental news in Canada. For a survey of these studies, see Lanoie, Laplante and Roy (1998).

${ }^{3}$ See Porter and Van Linde (1995), and Konar and Cohen (1997) for a more detailed discussion.
} 
indeed sought to complement or supplement traditional enforcement actions (fines and penalties) with the adoption of structured information programs (or public disclosure programs) by which the environmental performance of industrial facilities is revealed. Programs such as the Toxics Release Inventory (TRI) in the United States (also implemented in Canada and Great Britain), or the Proper Prokasih program in Indonesia and the EcoWatch program in the Philippines are examples of structured information programs that rely on non-regulatory forces to create incentives for (mainly industrial) facilities to improve environmental performance. ${ }^{4}$

While this may not be as well-known, the Republic of Korea (henceforth Korea) has developed its own extensive experience with the public disclosure of environmental performance of regulated facilities. Since the mid 1980s, the Ministry of Environment of Korea has published on a monthly basis a list of facilities in violation with existing Korean environmental laws and regulations. Over the sole period of 1993 to 2002, over 7,000 violations have been reported on those lists, involving more than 3,400 facilities. As such, the Korean experience with a structured public disclosure program may very well be one of the most extensive experiences of this nature in the world. ${ }^{5}$ In this paper, building upon the existing, albeit limited literature on this topic, we examine whether or not capital markets in Korea have reacted to the information contained in these monthly violation lists.

\footnotetext{
${ }^{4}$ See Foulon et al. (2002), Lanoie et al. (1998), and World Bank (2000) for a description of such programs. ${ }^{5}$ While it covers a larger number of years and facilities, the US TRI does not, by its very nature, focus necessarily on facilities in violation of existing laws and regulations.
} 
In the next section, we provide a brief description of the Korean public disclosure program. In Section 3, the event-study methodology is briefly described. We present the dataset and our results in Section 4, and conclude in Section 5.

\section{Description of the Korean public disclosure program ${ }^{6}$}

In the course of the rapid economic expansion of the 70 's and 80 's, the Government of Korea expressed a reluctance to strictly enforce its environmental regulations worrying to damage the economic performance and competitiveness of industrial facilities. On the other hand, there was mounting pressure on the Government to improve environmental protection in the country. It is in this context that the Monthly Violations Report (henceforth MVR) was first published in March 1984 by the Environment Administration as news material distributed to media reporters. The government's rationale behind the disclosure of the MVR was to provide incentives for industrial facilities not to practice illegal polluting activities while not resorting to legal fines and penalties. The MVR then consisted of a list of facilities in violation with existing Korean environmental laws and regulations. The violations included, among others, emission standard violation and failure to operate pollution control equipment. Given the limited monitoring capacity in terms both of financial and human resources, the MVR then had a very limited coverage.

In 1990, the Environment Administration became the Ministry of the Environment and was upgraded to the cabinet level, thereby being able to take greater charge of environmental policies and affairs within the government. The MVR disclosure

\footnotetext{
${ }^{6}$ For a detailed description, see Hong et al. (2003).
} 
program has continued throughout the 1990s. Under the Ministry, the program has enlarged considerably in terms of human and financial resources. A typical MVR in this period is based on information gathered through monthly government inspections on about 10,000 air and water polluting facilities, using a total of approximately 15,000 man-days from local governments and Regional Environmental Offices. Since November 1990, the Reports are also publicly disclosed through the Ministry of Environment official website, thus widening considerably its public outreach. ${ }^{7}$

While similar in spirit to the U.S. EPA's Toxics Release Inventory (TRI), the Korean MVR differs significantly from the TRI in that it reports the names of companies that are effectively deemed to be in violation of Korean environmental laws, as well as the nature of enforcement actions undertaken by the Ministry. The TRI is limited to reporting quantities of toxic wastes produced by a set of facilities, without attempting to assess the compliance status of these facilities. To this extent, the Korean MVR is conceptually similar to the lists by the Ministry of Environment, Lands and Parks of British Columbia (Canada) which aims to publicly disclose firms that either do not comply with the existing regulation or whose environmental performance is of concern to the Ministry. ${ }^{8}$

Over the period $1993-2002,{ }^{9}$ a total of 7,073 violation events appeared on a total of 113 violation lists published on a monthly basis. Over this period of observation, a

\footnotetext{
${ }^{7}$ See: www.me.go.kr

${ }^{8}$ See Foulon et al. (2002) for more details.

9 The Koran regulation pertaining to the length of time that information must be stored is such that all records previous to 1993 are unfortunately no longer available. While in this paper we shall refer to the
} 
total of 3,455 different facilities have appeared on the monthly violation lists, some more than once. The number of events and facilities indicates that on average each facility appeared 2.5 times on the violation lists. Most of these facilities $(85 \%)$ belong to the manufacturing sector. Of greater interest for the purpose of the current paper is that $17 \%$ of the facilities appearing on these lists are listed on the Korea Stock Exchange (KSE) whose headquarters are located in Seoul. While the percentage of events involving traded companies may appear relatively small (approximately 17\%), it is worth noting that in 2001, 690 companies were listed on the Korea Stock Exchange, out of a total of 106550 manufacturing firms with 5 employees or more, thus representing less than $1 \%$ of the total number of manufacturing facilities. This would suggest that traded companies are in fact overly represented in the monthly violation lists relative to their overall number in the population of enterprises in Korea.

Approximately $60 \%$ of the violations reported in the MVR pertain to the violation of Korean emissions standards. The second largest type of violation (18.0\%) is the failure of pollution abatement equipment to operate effectively. Insofar as government actions are concerned, the largest number (61\%) is government orders, followed with warning and prosecutions. Orders include orders to change equipment, and to appoint environmental management personnel. While a large number of facilities have been subjected to only 1 government action, an even larger number of facilities have received more than one government action. For example, 145 facilities have been subjected from 5 to 10 government actions; 13 facilities have received more than 20 government actions;

period 1993-2002, it should be understood that it also includes December 1992, while data for 2002 covers solely the period January to April 2002. 
the Busung Paper company has received the largest number of government actions with a total of 84 .

Since 1990, the Korea Press Foundation has operated a comprehensive online news database service known as KINDS (Korean Integrated News Database System). This system is the largest service of this nature in Korea. It covers national and economic daily newspapers in both Korean and English, news bulletins, local daily newspapers, magazines, and foreign newspapers. It provides the complete text of 10 major national daily newspapers. ${ }^{10}$ On-line users can further search articles in 23 local daily newspapers in Korea. Since its inception, it has cumulated a total of over 3 million articles, and continues to add to its database approximately 2,000 articles each and every day. The KINDS database was searched by entering keywords such as environment, violation, and accident, searching for articles related to environmental news.

Over the period of observation, approximately $11 \%$ of the total number of violation events that have appeared on the MVR have been covered by printed news media. In Table 1, note that of the 756 events covered in the printed news media, $40 \%$ of them involved traded companies. Given that traded companies represent only $17 \%$ of the total number of violation events, it would appear that news media show a particular attention to traded companies (which may also be larger and more prominent companies) in their news coverage of the MVR.

\footnotetext{
${ }^{10}$ The Kyunghyang Shinmun, the Kukmin Daily, the Korea Daily News, the Dong-A Ilbo, The Numhwa Ilbo, the Segye Ilbo, the Chosun Ilbo, the Joongang Ilbo, the Hankyoreh, and the Hankook Ilbo.
} 
Table 1

Media coverage: Traded vs. non-traded

\begin{tabular}{cc|cc|cc}
\hline \hline In news & Total & Traded & \% traded & Non-traded & $\begin{array}{c}\% \text { non- } \\
\text { traded }\end{array}$ \\
\hline No & 6317 & 887 & $14 \%$ & 5430 & $86 \%$ \\
Yes & 756 & 303 & $40 \%$ & 453 & $60 \%$ \\
\hline \hline
\end{tabular}

This greater interest in traded companies is also revealed by examining the number of newspapers in Korea that have given coverage to a specific violation event. In Table 2 , note that $39.3 \%$ of the events involving traded companies have been covered by more than 1 newspaper, while only $24.1 \%$ of the events involving non-traded companies have been covered in more than one newspaper.

Table 2

Frequency of news coverage: Traded vs. non-traded

\begin{tabular}{c|c|cc|cc}
\hline \hline $\begin{array}{c}\text { Number of newspapers that have } \\
\text { covered the event }\end{array}$ & Total & Traded & $\begin{array}{c}\text { \% } \\
\text { traded }\end{array}$ & $\begin{array}{c}\text { Non- } \\
\text { traded }\end{array}$ & $\begin{array}{c}\text { \% non- } \\
\text { traded }\end{array}$ \\
1 & 531 & 187 & 61.7 & 344 & 75.9 \\
2 & 137 & 64 & 21.1 & 73 & 16.1 \\
3 & 52 & 28 & 9.2 & 24 & 5.3 \\
4 & 21 & 15 & 5.0 & 6 & 1.3 \\
5 & 8 & 6 & 2.0 & 2 & 0.4 \\
6 & 4 & 2 & 0.7 & 2 & 0.4 \\
7 & 1 & & 0.0 & 1 & 0.2 \\
8 & 2 & 1 & 0.3 & 1 & 0.2 \\
Total & $\mathbf{7 5 6}$ & $\mathbf{3 0 3}$ & $\mathbf{1 0 0 . 0}$ & $\mathbf{4 5 3}$ & $\mathbf{1 0 0 . 0}$ \\
\hline \hline
\end{tabular}

Newspapers appear to be particularly interested by violations pertaining to the failure of pollution abatement equipment (Table 3). While this type of violation represents only $18.0 \%$ of the total number of events, it represents more than $25 \%$ of the events covered by newspapers. On the other hand, while the failure to report and failure of the monitoring system represent $9.2 \%$ of the total number of violations, these two types of violation represent only $5.5 \%$ of the events covered by the newspapers. 
Table 3

News coverage per type of violation

\begin{tabular}{lcc}
\hline \hline \multicolumn{1}{c}{ Nature of violation } & $\begin{array}{c}\text { \% of events covered } \\
\text { in news }\end{array}$ & $\begin{array}{c}\text { \% of total } \\
\text { events }\end{array}$ \\
\hline Violation of emissions standards & 53.9 & 60.8 \\
Failure of pollution abatement equipment & 25.1 & 18.0 \\
Failure to report & 3.4 & 5.3 \\
Failure of monitoring system & 2.1 & 3.9 \\
Failure of environmental manager & 1.9 & 3.6 \\
Violation of technical standards on inputs & 0.5 & 0.9 \\
Illegal waste discharges & 1.2 & 0.8 \\
Violation of government order & 0.6 & 0.7 \\
Other violation & 11.2 & 6.1 \\
\hline Total & $\mathbf{1 0 0 . 0}$ & $\mathbf{1 0 0 . 0}$ \\
\hline \hline
\end{tabular}

In terms of government actions, orders and warnings appears to receive less interest from the newspapers than their weight as a percentage of the total number of violation events (Table 4). However, while prosecutions represent only $9.9 \%$ of the total violation events, they represent almost $16 \%$ of the violation events reported in the newspapers. Similarly, shutdowns (temporary or complete) and bans receive more attention in newspapers $(7.5 \%$ of all events in the newspapers) than their overall importance in the monthly violation lists (11.8\% of all violation events). 
Table 4

News coverage per type of government actions

\begin{tabular}{lcc}
\hline \hline Government actions & $\begin{array}{c}\text { \%o of events covered } \\
\text { in news }\end{array}$ & $\begin{array}{c}\text { \% of total } \\
\text { events }\end{array}$ \\
\hline Order & 53.9 & 61.3 \\
Warning & 8.1 & 11.4 \\
Prosecution & 15.8 & 9.9 \\
Penalty & 4.2 & 7.1 \\
Temporary shutdown & 5.8 & 4.3 \\
Shutdown & 6.0 & 3.2 \\
Ban to use specific equipment & 6.0 & 2.8 \\
Other & 0.1 & 0.1 \\
\hline Total & 100.0 & $\mathbf{1 0 0 . 0}$ \\
\hline \hline
\end{tabular}

The above information indicates that newspapers have indeed paid attention to the information released by the Ministry of the Environment in its MVR, and that the media coverage has focused very significantly on publicly traded companies. This therefore sets the stage for an analysis of how the Korean Stock Market reacted to the media coverage of the MVR.

\section{Event-study methodology}

The event-study methodology is used here to see the extent to which investors react to environmental news (also called events). ${ }^{11}$ The key assumption of the methodology is that capital markets are sufficiently efficient to evaluate the impact of new information (events) on expected future profits of the firms.

The methodology involves the following steps: (1) identification of the events of interest and definition of the event window; ${ }^{12}$ (2) selection of the sample set of firms to

\footnotetext{
11 For more details, see MacKinlay (1997).

12 The event window consists of the day where the event occurred (day 0 ) and some days before and after the event.
} 
include in the analysis; ${ }^{13}$ (3) prediction of a "normal" return during the event window in the absence of the event; (4) estimation of the abnormal return within the event window, where the abnormal return is defined as the difference between the actual and predicted returns; and (5) testing whether the abnormal return is statistically different from zero. The market model is of interest here to estimate abnormal returns.

The market model assumes a linear relationship between the return of any security to the return of the market portfolio:

$$
R_{i t}=\alpha_{i}+\beta_{i} R_{m t}+e_{i t}
$$

$$
\text { with } E\left(e_{i t}\right)=0 \quad \text { and } \operatorname{Var}\left(e_{i t}\right)=\sigma_{e_{i}}^{2}
$$

where $t$ is the time index, $i=1,2, \ldots, N$ stands for security, $R_{i t}$ and $R_{m t}$ are the returns on security $i$ and the market portfolio respectively during period $t$, and $e_{i t}$ is the error term for security $i$.

Equation (1) is generally estimated over a period which runs between 120 and 210 days prior to the event up to some days prior to the event. The event window is defined as the period from some days prior to the event to some days after the event. The size of the event window is really an empirical matter. With the estimates of $\alpha_{i}$ and $\beta_{i}$ from equation (1), one can predict a "normal" return during the days covered by the event window. The prediction error (the difference between the actual return and the predicted

\footnotetext{
${ }^{13}$ Firms may be excluded if simultaneous events are occurring within the event window.
} 
normal return), commonly referred to as the abnormal return (AR) for a single security $\mathrm{i}$ at a given time $t$, is then calculated as:

$$
A R_{i t}=R_{i t}-\hat{\alpha}_{i}-\hat{\beta}_{i} R_{m t}
$$

Under the null hypothesis, the abnormal returns will be jointly normally determined with a zero conditional mean and conditional variance $\sigma^{2}\left(A R_{i t}\right)$ :

$$
\sigma^{2}\left(A R_{i t}\right)=\sigma_{e_{i}}^{2}+\frac{1}{L}\left[1+\frac{\left(R_{m t}-\bar{R}_{m}\right)^{2}}{\sigma_{m}^{2}}\right]
$$

where $L$ is the estimation period length (i.e. number of days used for estimation) and $\bar{R}_{m}$ is the mean of the market portfolio. With $L$ large, $\sigma^{2}\left(A R_{i t}\right) \rightarrow \sigma_{e_{i}}^{2}$.

For each individual event, one can estimate the abnormal return and relevant test statistics at each instant in time within the event window. However, in order to draw overall inference about the reaction of capital markets, one can also aggregate the abnormal returns across a number of events (usually across events of a similar nature). Hence, for any given subset of $\mathrm{N}$ events (or securities), the subset average abnormal returns $\left(A A R_{t}\right)$ at each instant $t$ within the event window is computed as

$$
A A R_{t}=\frac{1}{N} \sum_{i=1}^{N} A R_{i t}
$$


For large $L$, the variance is

$$
\operatorname{VAR}\left(A A R_{t}\right)=\frac{1}{N^{2}} \sum_{i=1}^{N} \sigma_{e_{i}}^{2}
$$

To test for the significance of $A A R_{t}$ a $Z$ (or $t$ ) test can be derived.

In order to test for the persistence of the impact of the event during a period $\left(T_{2}-T_{1}\right)$, the abnormal return for a given security $\mathrm{i}$ can also be added to obtain the cumulated abnormal returns $\left(\operatorname{CAR}_{i}\left(T_{1}, T_{2}\right)\right)$ for security $i$ over the period $\left(T_{2}-T_{1}\right)$ :

$$
\operatorname{CAR}_{i}\left(T_{1}, T_{2}\right)=\sum_{t=T_{1}}^{T_{2}} A R_{i t}
$$

where $T_{a} \leq T_{1}<t<T_{2} \leq T_{b} \in$ event window, and $T_{a}$ and $T_{b}$ are the lower and upper limits of the event window, respectively. ${ }^{14}$ Asymptotically (as $L$ increases) the variance of the cumulative abnormal return for security $i$ is

$$
\sigma_{i}^{2}\left(T_{1}, T_{2}\right)=\left(T_{2}-T_{1}+1\right) \sigma_{e_{i}}^{2}
$$

To test the null hypothesis of zero cumulative abnormal return, one can formulate a $\mathrm{Z}$ test as $\operatorname{CAR}_{i}\left(T_{i}, T_{2}\right) \sim N\left(0, \sigma_{i}^{2}\left(T_{i}, T_{2}\right)\right.$ :

$$
Z=\frac{C A R}{\left(\sigma_{i}^{2}\left(T_{1}, T_{2}\right)\right)^{1 / 2}} \sim N(0,1)
$$

${ }^{14} T_{1}$ and $T_{2}$ are thus contained within the event window and the aggregation of the abnormal return takes place between those days within the window. As a possibility, $T_{l}$ can coincide with the lower bound of the event window and $T_{2}$ with the upper bound. 
An aggregation of interest can also be performed across both time and events. In that scenario, the average cumulative abnormal return for a subset of $\mathrm{N}$ events between two dates $T_{1}$ and $T_{2}$ is defined as:

$$
\operatorname{CAAR}\left(T_{1}, T_{2}\right)=\frac{1}{N} \sum_{i=1}^{N} \operatorname{CAR}_{i}\left(T_{1}, T_{2}\right)
$$

where $\mathrm{N}$ is the number of events. The variance of $C A A R$ is

$$
\operatorname{var}\left(C A A R\left(T_{1}, T_{2}\right)\right)=\frac{1}{N^{2}} \sum_{i=1}^{N} \sigma_{i}^{2}\left(T_{1}, T_{2}\right)
$$

Under the null hypotheses that the abnormal returns are zero,

$$
Z=\frac{C A A R\left(T_{1}, T_{2}\right)}{\left(\operatorname{var}\left(C A A R\left(T_{1}, T_{2}\right)\right)\right)^{1 / 2}} \sim N(0,1)
$$

As pointed out by MacKinlay (1997), this distributional result is asymptotic with respect to the number of securities $N$ and the length of estimation window $L$. Moreover, the validity of cross-sectional (or pooled) aggregation of abnormal returns rests on the assumption that the event windows do not overlap. If they do then the distributional results presented above are no longer valid since covariances across securities are no longer zero, particularly in the case of complete clustering. There are two solutions to the problem of clustering. The first one is to aggregate abnormal returns into portfolios. The 
second one is basically to leave abnormal returns unaggregated; that is, one has to deal with abnormal returns security by security (for details, see MacKinlay, 1997, 27).

In the next section, we present results obtained from using the single-index model (constant mean return model). ${ }^{15}$

\section{Dataset and Results}

The initial dataset comprises 96 environmental news (details appear in Appendix 1). These events were examined to identify whether or not other events (positive or negative) were observed during the identified window. These confounding events could impact the results from the event-study methodology. As a result, 9 events were eliminated from the dataset. ${ }^{16}$ Thus, the dataset used for the analysis of stock market reaction comprises 87 environmental news involving 57 publicly traded firms over the period 1993 to 2000. All events are of a negative nature. Of the 87 events, 57 (65.5\%) pertains to the violation of emissions standards, while $17(19.5 \%)$ pertain to the failure to operate pollution abatement equipment.

We apply the event-study methodology to each of these 87 events. The study uses an estimation period of 210 days before the event window and an event window of 7 days ( 3 days prior the event, the day of the announcement, and 3 days after the event).

\footnotetext{
15 The single-index model is a particular case of the market model described above. Where market returns were available, we also obtained results using the market model. Results were similar to those presented here. In fact, Henderson (1990) points out that the three estimating methodologies yield results of similar nature.

${ }^{16}$ These are (by code number): 210 (3/4/99), 2270 (12/1/99 and 11/3/99), 2580 (8/31/96), 4800 (8/27/99), 5300 (7/1/94), $9830(12 / 30 / 96), 11780(1 / 30 / 97)$, and $15760(8 / 1 / 96)$.
} 
The latter size of the event window has been determined empirically through a search over a period of 10 days before and 10 days after the event.

Appendix 2 presents the list of 87 events and differentiates those events for which a statistically significant stock market reaction has been estimated from those for which no such reaction has been estimated. Detailed statistical results for those events with market reaction are presented in Appendix 3.

As shown in Appendix 2, 52 of the 87 events $(60 \%)$ included in our dataset show a statistically significant market reaction. However, 5 of these exhibit a positive market reaction. ${ }^{17}$ We were not able to identify whether or not these 5 events were plagued by the presence of simultaneous, positive, events. We cannot therefore offer a credible explanation for the unexpected market reaction for these 5 events. Of those events with negative market reactions, the average percentage reduction in market value has been calculated to be $9.7 \%$. As shown in Table 5 below, this average reduction in market value is much higher than results obtained in Canada and the United States, but of a similar order of magnitude as results obtained in Argentina, Chile, Mexico, and the Philippines (Dasgupta et al. (2001)). This would tend to re-enforce the hypothesis that capital markets in developing countries may attach a greater premium to information which otherwise may generally not be as readily available as in more developed markets.

\footnotetext{
${ }^{17}$ These events are (by code number): 1440 (9/27/93), 1460 (4/27/93), 2270 (1/20/2000), 9840 (3/1/94), and $25830(8 / 31 / 96)$.
} 
Table 5

Comparative results

\begin{tabular}{|l|l|l|c|}
\hline \multicolumn{1}{|c|}{ Selected studies } & \multicolumn{1}{|c|}{ Events } & \multicolumn{1}{|c|}{ Media } & \multicolumn{1}{|c|}{$\begin{array}{c}\text { Observed } \\
\text { Reaction }\end{array}$} \\
\hline Muoghalu et al. (1990) & $\begin{array}{l}\text { Filing of lawsuit for } \\
\text { violation of RCRA }\end{array}$ & Newspaper (USA) & $-1.2 \%$ \\
\hline $\begin{array}{l}\text { Lanoie and Laplante } \\
(1994)\end{array}$ & $\begin{array}{l}\text { Court finds firm guilty } \\
\text { for violating environ. } \\
\text { Regulation }\end{array}$ & $\begin{array}{l}\text { Newspaper } \\
\text { (Canada) }\end{array}$ & $-1.65 \%$ \\
\hline $\begin{array}{l}\text { Klassen and McLaughlin } \\
(1996)\end{array}$ & Environmental crisis & Newspaper (USA) & $-1.5 \%$ \\
\hline Hamilton (1995) & List of polluters & $\begin{array}{l}\text { Toxics Release } \\
\text { Inventory (USA) }\end{array}$ & $-0.3 \%$ \\
\hline Konar and Cohen (1997) & List of polluters & $\begin{array}{l}\text { Toxics Release } \\
\text { Inventory (USA) }\end{array}$ & $-1.3 \%$ \\
\hline $\begin{array}{l}\text { Lanoie, Laplante, and Roy } \\
(1998)\end{array}$ & List of polluters & $\begin{array}{l}\text { British Columbia } \\
\text { (Canada) }\end{array}$ & $-2 \%$ \\
\hline Dasgupta et al. (2001) & $\begin{array}{l}\text { Citizens complaints and } \\
\text { environmental accidents }\end{array}$ & $\begin{array}{l}\text { Newspaper } \\
\text { (Argentina, Chile, } \\
\text { Mexico and } \\
\text { Philippines) }\end{array}$ & $-4 \%$ to -15\% \\
\hline
\end{tabular}

${ }^{\text {a }}$ Average estimated change in market return.

${ }^{\mathrm{b}}$ Resource Conservation and Recovery Act.

If we include all events with market reaction, we note in Table 6 that $69 \%(36 / 52)$ of the events with market reaction are violation of emission standard, which is a slightly higher percentage than the percentage of those events in our dataset $(65 \%)$. On the other hand, the failure to operate PCE properly represents only $15 \%$ of those events exhibiting market reaction, which is a slightly lower percentage than the share of those events in the dataset. This would appear to indicate, perhaps as may have been expected, that the market react slightly more frequently to the violation of emission standard than to the failure to operate PCE properly. However, the average percentage reduction of market value for those events pertaining to the violation of emission standard is $8.96 \%$, while the average reduction is calculated to be $15.3 \%$ for those events pertaining to the failure of operating PCE properly. It should be noted however that we accept the null hypothesis at 
the $10 \%$ level of significance that there is no significant difference between negative market reaction from events of violation of emission standard and that of events of failure to operate PCE properly. ${ }^{18}$

\section{Table 6}

Market reaction per type of events

\begin{tabular}{|l|c|c|c|}
\hline & $\begin{array}{c}\text { Violation of } \\
\text { emission standard }\end{array}$ & $\begin{array}{c}\text { Failure to operate } \\
\text { PCE properly }\end{array}$ & Other \\
\hline $\begin{array}{l}\text { With market } \\
\text { reaction }\end{array}$ & 36 & 8 & 8 \\
\hline $\begin{array}{l}\text { Without market } \\
\text { reaction }\end{array}$ & 21 & 9 & 5 \\
\hline Total & 57 & 17 & 13 \\
\hline
\end{tabular}

All other things being equaled, it may further be assumed that markets have increasingly reacted to environmental news over the period of analysis as environmental awareness may have increased throughout society. This however does not appear to be case as shown in Table 7. Moreover, we have grouped the events into 3 different subgroups: (1) a sub-group covering the period 1992-1994; (2) a sub-group covering 1996; and (3) another sub-group covering 1999. Our results show that the average percentage reductions in market value were $13.8 \%, 4.58 \%$, and $8.21 \%$ respectively. A statistical test reveals that the difference in these changes is indeed statistically significant. ${ }^{19}$ This would appear to indicate that from its initial large impact, the MVR may have lost some of its capacity to generate incentives for pollution control. On the other hand, even though the reduction in market value may have lessen over time, such percentage reductions do remain significantly lower than those observed in Canada and the United States (Table 5).

\footnotetext{
${ }^{18}$ See Appendix 5 for details.

${ }^{19}$ See Appendix 6 for details.
} 
Table 7

Number of events with and without market reaction over time

\begin{tabular}{|c|c|c|}
\hline & With market reaction & Without market reaction \\
\hline $\mathbf{1 9 9 2}$ & 1 & 0 \\
\hline $\mathbf{1 9 9 3}$ & 14 & 12 \\
\hline $\mathbf{1 9 9 4}$ & 12 & 6 \\
\hline $\mathbf{1 9 9 5}$ & 0 & 5 \\
\hline $\mathbf{1 9 9 6}$ & 15 & 8 \\
\hline $\mathbf{1 9 9 7}$ & 0 & 0 \\
\hline $\mathbf{1 9 9 8}$ & 0 & 0 \\
\hline $\mathbf{1 9 9 9}$ & 10 & 6 \\
\hline $\mathbf{2 0 0 0}$ & 0 & 3 \\
\hline
\end{tabular}

Finally, we examine whether or not the extent of news coverage by media (as measured by the number of newspapers that have covered by the environmental events) may have an impact on the nature and extent of the market reaction. Appendix 4 reports the presence or absence of market reaction for each event, along with the number of newspapers that have reported the particular event. Of those events with market reaction, the average number of newspaper that have covered the event amounts to 1.89 per event; of those events without market reaction, the average number of news coverage is 1.77 . Though the difference may not be very large, it does support the assumption that the larger the number of newspapers coverage, the greater the likelihood of market reaction. To this effect, it may be further noted that the 2 events which have been covered by 5 newspapers, and the (one) event that has been covered by 6 newspapers have all experienced market reaction. We have also grouped these events into 3 sub-groups: (1) a sub-group of events which have been covered by 1 or 2 newspapers; (2) a sub-group of events which have been covered by 3, 4, 5 and 6 newspapers; (3) a sub-group of events which have received coverage by 5 or 6 newspapers. Our results reveal an average 
percentage reduction of market value for each of these sub-groups of $4.46 \%, 16.1 \%$, and $38.23 \%$ respectively. ${ }^{20}$ It would thus appear that the larger or wider the coverage of the events by newspapers, which may itself be reflective of the nature and/or importance of the event, the larger the percentage reduction in market value.

\section{Conclusion}

Since the late 1980 's, the government of Korea has actively implemented a public disclosure program to inform citizens of the fact that some large companies in Korea are not complying with Korean environmental laws and regulations. Perhaps contrary to expectations that capital markets in developing countries may not reach to such news, it was shown in this paper that investors on the Korean Stock Exchange do in fact strongly react to the disclosure of such news. The average reduction in market value was estimated to be much higher than the estimated changes in market value for similar events in Canada and the United States, and of a similar magnitude as observed changes in other developing countries (Argentina, Chile, Mexico, and Philippines). It was further shown that the larger the extent of coverage by newspapers, the larger the reduction in market value, reaching above 35\% for those events covered by 5 or more newspapers.

While a number of papers have examined the reaction of stock markets to environmental news, it is not immediately clear whether or not such reactions then induced changes in the actual environmental performance of the involved facilities. This is subject to on-going research.

\footnotetext{
${ }^{20}$ The difference between these percentage reductions in market value is statistically significant. See Appendix 7 for details.
} 


\section{References}

Afsah, S., Laplante, B. and D. Wheeler (1996), Controlling Industrial Pollution: A New Paradigm, Policy Research Working Paper 1672, The World Bank.

Blackman, A., and G.J. Bannister (1998), "Community pressure and clean technology in the informal sector: An econometric analysis of the adoption of propane by traditional Mexican brick makers", Journal of Environmental Economics and Management, 35, 1-21.

Dasgupta, S., Laplante, B. and N. Mamingi (2001), "Pollution and Capital Markets in Developing Countries", Journal of Environmental Economics and Management, 42, 310-335.

Foulon, J. Lanoie, P., and B. Laplante (2002), "Incentives for pollution control: Regulation or information?", Journal of Environmental Economics and Management, 44, 169-187.

Hamilton, T. (1995), "Pollution as news: Media and stock market reaction to the Toxics Release Inventory data", Journal of Environmental Economics and Management, 28, 98-113.

Henderson, G. V. (1990), "Problems and solutions in conducting events studies", Journal of Risk and Insurance, 42, 282-306.

Hong, J.H, Laplante, B., and C. Meisner (2003), Public Disclosure of Environmental Violations in the Republic of Korea, World Bank Working Paper 3126, Washington, D.C.

Klassen, R.D. and C.P. McLaughlin (1996), "The impact of environmental management on firm performance", Management Science, 42, 8, 1199-1214 (1996).

Konar, S. and M.A. Cohen (1997), "Information as regulation: The effect of community right to know laws on toxic emissions", Journal of Environmental Economics and Management, 32, 109-124.

Lanoie, P. and B. Laplante (1994), "The market response to environmental incidents in Canada: a theoretical and empirical analysis", Southern Economic Journal, 60, 657-72.

Lanoie, P., Laplante, B. and M. Roy (1998), "Can Capital Markets Create Incentives for Pollution Control?”, Ecological Economics, 26, 1998, 31-41.

MacKinlay, A.C. (1997), "Event studies in economics and finance", Journal of Economic Literature, 35, 1, 13-39. 
Muoghalu, M.I., Robison, H. and J.L. Glascock (1990), "Hazardous waste lawsuits, stockholder returns, and deterrence", Southern Economic Journal, 357-370 (1990).

Ott, R.L. and M. Longnecker (2001), An Introduction to Statistical Methods and Data Analysis, Pacific Grove: Duxbury.

Pargal, S. and D. Wheeler (1996), "Informal regulation of industrial pollution in developing countries: Evidence from Indonesia", Journal of Political Economy, $104,1314-27$.

Porter, M. E. and van der Linde, C., (1995). Toward a new conception of the Environment-Competitiveness relationship. Journal of Economic Perspectives, 9, 4, 97-118.

World Bank (2000), Greening Industry: New Roles for Communities, Markets and Governments, Washington, D.C. 


\section{Appendix 1 \\ Description of the dataset}

\begin{tabular}{|c|c|c|c|}
\hline Code & Company Name & Event date & Nature of Event \\
\hline 80 & Jinro & $5 / 31 / 1994$ & Emission standard violation \\
\hline 140 & Hite Brewery Co. Ltd & $4 / 27 / 1993$ & Emission standard violation \\
\hline 210 & Daelim Industrial Co. Ltd & 7/22/1993 & Failure to operate PCE properly \\
\hline 210 & Daelim Industrial Co. Ltd & 3/4/1999 & Emission standard violation \\
\hline 210 & Daelim Industrial Co. Ltd & $12 / 28 / 1999$ & Emission standard violation \\
\hline 240 & Hankook Tire Co. Ltd & 7/22/1993 & Emission standard violation \\
\hline 240 & Hankook Tire Co. Ltd & 7/6/1996 & Emission standard violation \\
\hline 240 & Hankook Tire Co. Ltd & $8 / 26 / 1999$ & Emission standard violation \\
\hline 270 & Kia Motors & $8 / 26 / 1999$ & Emission standard violation \\
\hline 990 & Dongbu Hannong Chemical Co. Ltd & $6 / 23 / 1993$ & Violation of measures on environmental manager \\
\hline 990 & Dongbu Hannong Chemical Co. Ltd & $4 / 28 / 1994$ & Emission standard violation \\
\hline 990 & Dongbu Hannong Chemical Co. Ltd & $5 / 4 / 1996$ & Failure to operate PCE properly \\
\hline 1390 & Gyeonggi Chemical & $8 / 28 / 1994$ & Use of equipment without government permission \\
\hline 1390 & Gyeonggi Chemical & $8 / 31 / 1996$ & Failure to operate PCE properly \\
\hline 1430 & Kia Steel Co. Ltd & $8 / 27 / 1993$ & Emission standard violation \\
\hline 1430 & Kia Steel Co. Ltd & $12 / 29 / 1996$ & Emission standard violation \\
\hline 1440 & Taihan Electric Wire Co. Ltd & 9/27/1993 & Emission standard violation \\
\hline 1460 & BYC Co. Ltd & $4 / 27 / 1993$ & Emission standard violation \\
\hline 1630 & Chongkundang Pharmaceutical Co. & 8/1/1996 & Emission standard violation \\
\hline 1740 & SK Corporation & 7/20/1999 & Use of equipment without government permission \\
\hline 1740 & SK Corporation & 7/29/1999 & Use of equipment without government permission \\
\hline 2030 & Asia Cement Industry & $8 / 28 / 1994$ & Failure to operate PCE properly \\
\hline 2030 & Asia Cement Industry & $10 / 28 / 1996$ & Emission standard violation \\
\hline 2030 & Asia Cement Industry & $12 / 30 / 1996$ & Emission standard violation \\
\hline 2170 & Samyang Tongsang Co. Ltd & $4 / 3 / 1993$ & Use of equipment without government permission \\
\hline 2270 & Lotte samkang Co. Ltd & $11 / 3 / 1999$ & Violation of standard on offensive odor \\
\hline 2270 & Lotte samkang Co. Ltd & $12 / 1 / 1999$ & Emission standard violation \\
\hline 2270 & Lotte samkang Co. Ltd & $1 / 20 / 2000$ & Emission standard violation \\
\hline 2310 & Asia Paper & $7 / 22 / 1993$ & Emission standard violation \\
\hline 2450 & Samick Musical Instruments Co. Ltd & $1 / 26 / 1994$ & Failure to operate PCE properly \\
\hline 2580 & Sammi Steel Co. Ltd & $8 / 31 / 1996$ & Failure to operate PCE properly \\
\hline 2840 & Miwon Commercial Co. Ltd & $10 / 28 / 1996$ & Emission standard violation \\
\hline 3190 & Daewon Paper & 9/27/1993 & Failure to operate PCE properly \\
\hline 3190 & Daewon Paper & $10 / 28 / 1996$ & Failure to employ environmental manager \\
\hline 3230 & Samyang Foods Co. Ltd & $4 / 4 / 1993$ & Failure to employ full-time environmental manager \\
\hline 3230 & Samyang Foods Co. Ltd & $8 / 1 / 1996$ & Emission standard violation \\
\hline 3240 & Taekwang Industrial Co. Ltd & $4 / 27 / 1994$ & Emission standard violation \\
\hline 3240 & Taekwang Industrial Co. Ltd & $8 / 27 / 1999$ & Emission standard violation \\
\hline 3410 & Ssangyong Cement Industrial Co. Ltd & $4 / 27 / 1993$ & Emission standard violation \\
\hline 3920 & Namyang Dairy Products Co. Ltd & $7 / 22 / 1993$ & Emission standard violation \\
\hline 3920 & Namyang Dairy Products Co. Ltd & 7/6/1996 & Emission standard violation \\
\hline 3980 & Hanil Synthetic Fiber Co. Ltd & $4 / 27 / 1994$ & Failure to operate PCE properly \\
\hline 3980 & Hanil Synthetic Fiber Co. Ltd & $5 / 31 / 1994$ & Failure to operate PCE properly \\
\hline 4370 & Nong Shim Co. Ltd & $9 / 27 / 1993$ & Emission standard violation \\
\hline 4460 & Kohap Corporation & $4 / 27 / 1993$ & Use of equipment without government permission \\
\hline 4460 & Kohap Corporation & $6 / 24 / 1993$ & Emission standard violation \\
\hline
\end{tabular}


4690

4800

4980

5070

5070

5070

5180

5300

5300

5300

5420

5490

5600

5740

5810

5810

5950

6040

6070

6390

6390

6390

6400

7410

7410

7810

8720

8900

8900

8970

9580

9830

9840

9840

9840

10140

10780

10780

11780

11780

14580

15760

15760

15760

16380

16380

16380

23150

25830

25860
Samchully Co. Ltd

Hyosung Co. Ltd

Sungshin Cement Mfq. Corp.

Saehan Media Co. Ltd

Saehan Media Co. Ltd

Saehan Media Co. Ltd

Binggrae

Lotte Chilsung Beverage Co. Ltd

Lotte Chilsung Beverage Co. Ltd

Lotte Chilsung Beverage Co. Ltd

Hankook Titanium Industry

Pohang Iron \& Steel Co., Ltd

Joongang Paper

Crown Confectionary Co. Ltd

Pungsan

Pungsan

Isuchemical Co. Ltd

Dongwon Industries Co. Ltd

Kirin

Hyundai Cement Industrial

Hyundai Cement Industrial

Hyundai Cement Industrial

Samsung SDI Co. Ltd

Daewoo Electronics Co. Ltd

Daewoo Electronics Co. Ltd

Korea Cerkit

Samyang Heavy Machinery Co.

SBW Co. Ltd

SBW Co. Ltd

Dongyangcheolgwan

Donghae Pulp Co. Ltd

Hanwha Chemical Co. Ltd

Kabool Co. Ltd

Kabool Co. Ltd

Kabool Co. Ltd

Samsung Heavy Industries Co. Ltd

Dongseo Industrial

Dongseo Industrial

Kumho Petrochemical Co. Ltd

Kumho Petrochemical Co. Ltd

Bakgwang Material

Korea Electric Power Corporation

Korea Electric Power Corporation

Korea Electric Power Corporation

Dongbu Steel Co. Ltd

Dongbu Steel Co. Ltd

Dongbu Steel Co. Ltd

Muhak Jujeong

Hankook Synthetic Fiber

Namhae Chemical
4/3/1993 Use of equipment without government permission

8/27/1999 Emission standard violation

10/28/1996 Emission standard violation

4/3/1993 Emission standard violation

8/27/1993 Emission standard violation

$8 / 1 / 1996$

$1 / 31 / 2000$

$7 / 22 / 1993$

$7 / 1 / 1994$

$7 / 29 / 1999$

$2 / 6 / 1992$

$11 / 30 / 1996$

$9 / 27 / 1993$

$11 / 3 / 1999$

$9 / 27 / 1993$

$7 / 30 / 1996$

$7 / 20 / 1999$

$3 / 4 / 1999$

$3 / 11 / 1993$

$4 / 27 / 1993$

$10 / 28 / 1996$

$12 / 30 / 1996$

$8 / 22 / 1996$

$8 / 28 / 1994$

$8 / 31 / 1996$

$10 / 1 / 1994$

$11 / 30 / 1993$

$6 / 23 / 1993$

$12 / 25 / 1994$

$1 / 26 / 1994$

$7 / 1 / 1994$

12/30/1996

$3 / 1 / 1994$

$3 / 30 / 1994$

$4 / 27 / 1994$

$12 / 25 / 1994$

$7 / 1 / 1994$

$12 / 1 / 1999$

$7 / 6 / 1996$

$1 / 30 / 1997$

$12 / 28 / 1999$

$8 / 1 / 1996$

7/29/1999

$8 / 27 / 1999$

$8 / 31 / 1996$

$6 / 30 / 1999$

$8 / 27 / 1999$

$1 / 31 / 2000$

$8 / 31 / 1996$

$11 / 30 / 1996$

Emission standard violation

Emission standard violation

Emission standard violation

Emission standard violation

Emission standard violation

Emission standard violation

Failure to operate PCE properly

Emission standard violation

Emission standard violation

Emission standard violation

Failure to operate PCE properly

Emission standard violation

Emission standard violation

Use of equipment without government permission

Failure to operate PCE properly

Emission standard violation

Emission standard violation

Emission standard violation

Emission standard violation

Emission standard violation

Failure to operate PCE properly

Failure to operate PCE properly

Emission standard violation

Emission standard violation

Failure to operate PCE properly

Emission standard violation

Emission standard violation

Emission standard violation

Emission standard violation

Emission standard violation

Failure to operate PCE properly

Failure to operate PCE properly

Emission standard violation

Emission standard violation

Violation of measures on environmental manager

Emission standard violation

Emission standard violation

Use of equipment without government permission

Emission standard violation

Emission standard violation

Polluting water resource

Polluting water resource

Emission standard violation

Emission standard violation

Failure to operate PCE properly 
Appendix 2

Market reaction / No reaction to event

\begin{tabular}{|c|c|c|c|c|}
\hline Code & Company Name & Reaction & No Reaction & Nature of Event \\
\hline 80 & Jinro & & $5 / 31 / 1994$ & Emission standard violation \\
\hline 140 & Hite Brewery Co. & $4 / 27 / 1993$ & & Emission standard violation \\
\hline 210 & Daelim Industrial Co. & & $7 / 22 / 1993$ & Failure to operate PCE properly \\
\hline 210 & Daelim Industrial Co. & $12 / 28 / 1999$ & & Emission standard violation \\
\hline 240 & Hankook Tire Co. & $7 / 22 / 1993$ & & Emission standard violation \\
\hline 240 & Hankook Tire Co. & & $7 / 6 / 1996$ & Emission standard violation \\
\hline 240 & Hankook Tire Co. & & $8 / 26 / 1999$ & Emission standard violation \\
\hline 270 & Kia Motors & & $8 / 26 / 1999$ & Emission standard violation \\
\hline 990 & Dongbu Hannong Chemical Co. & $6 / 23 / 1993$ & & Violation of measures on environmental manager \\
\hline 990 & Dongbu Hannong Chemical Co. & & 4/28/1994 & Emission standard violation \\
\hline 990 & Dongbu Hannong Chemical Co. & $5 / 4 / 1996$ & & Failure to operate PCE properly \\
\hline 1390 & Gyeonggi Chemical & & $8 / 28 / 1994$ & Use of equipment without government permission \\
\hline 1390 & Gyeonggi Chemical & & $8 / 31 / 1996$ & Failure to operate PCE properly \\
\hline 1430 & Kia Steel Co. & & $8 / 27 / 1993$ & Emission standard violation \\
\hline 1430 & Kia Steel Co. & & $12 / 29 / 1996$ & Emission standard violation \\
\hline 1440 & Taihan Electric Wire Co. & 9/27/1993 & & Emission standard violation \\
\hline 1460 & BYC Co. & $4 / 27 / 1993$ & & Emission standard violation \\
\hline 1630 & Chongkundang Pharmaceutical Co. & $8 / 1 / 1996$ & & Emission standard violation \\
\hline 1740 & SK Co. & $7 / 20 / 1999$ & & Use of equipment without government permission \\
\hline 1740 & SK Co. & $7 / 29 / 1999$ & & Use of equipment without government permission \\
\hline 2030 & Asia Cement Industry & & $8 / 28 / 1994$ & Failure to operate PCE properly \\
\hline 2030 & Asia Cement Industry & $10 / 28 / 1996$ & & Emission standard violation \\
\hline 2030 & Asia Cement Industry & $12 / 30 / 1996$ & & Emission standard violation \\
\hline 2170 & Samyang Tongsang Co. & & $4 / 3 / 1993$ & Use of equipment without government permission \\
\hline 2270 & Lotte samkang Co. & & $1 / 20 / 2000$ & Emission standard violation \\
\hline 2310 & Asia Paper & $7 / 22 / 1993$ & & Emission standard violation \\
\hline 2450 & Samick Musical Instruments Co. & $1 / 26 / 1994$ & & Failure to operate PCE properly \\
\hline 2840 & Miwon Commercial Co. & $10 / 28 / 1996$ & & Emission standard violation \\
\hline 3190 & Daewon Paper & & 9/27/1993 & Failure to operate PCE properly \\
\hline 3190 & Daewon Paper & $10 / 28 / 1996$ & & Failure to employ environmental manager \\
\hline 3230 & Samyang Foods Co. & & $4 / 4 / 1993$ & Failure to employ full-time environmental manager \\
\hline 3230 & Samyang Foods Co. & $8 / 1 / 1996$ & & Emission standard violation \\
\hline 3240 & Taekwang Industrial Co. & $4 / 27 / 1994$ & & Emission standard violation \\
\hline 3240 & Taekwang Industrial Co. & 8/27/1999 & & Emission standard violation \\
\hline 3410 & Ssangyong Cement Industrial Co. & $4 / 27 / 1993$ & & Emission standard violation \\
\hline 3920 & Namyang Dairy Products Co. & $7 / 22 / 1993$ & & Emission standard violation \\
\hline 3920 & Namyang Dairy Products Co. & $7 / 6 / 1996$ & & Emission standard violation \\
\hline 3980 & Hanil Synthetic Fiber Co. & $4 / 27 / 1994$ & & Failure to operate PCE properly \\
\hline 3980 & Hanil Synthetic Fiber Co. & & $5 / 31 / 1994$ & Failure to operate PCE properly \\
\hline 4370 & Nong Shim Co. & $9 / 27 / 1993$ & & Emission standard violation \\
\hline 4460 & Kohap Co. & 4/27/1993 & & Use of equipment without government permission \\
\hline 4460 & Kohap Co. & & $6 / 24 / 1993$ & Emission standard violation \\
\hline 4690 & Samchully Co. & & 4/3/1993 & Use of equipment without government permission \\
\hline 4980 & Sungshin Cement Mfq. Co. & & $10 / 28 / 1996$ & Emission standard violation \\
\hline 5070 & Saehan Media Co. & & $4 / 3 / 1993$ & Emission standard violation \\
\hline 5070 & Saehan Media Co. & & $8 / 27 / 1993$ & Emission standard violation \\
\hline
\end{tabular}




\begin{tabular}{|c|c|c|c|c|}
\hline 5070 & Saehan Media Co. & 8/1/1996 & & Emission standard violation \\
\hline 5180 & Binggrae & & $1 / 31 / 2000$ & Emission standard violation \\
\hline 5300 & Lotte Chilsung Beverage Co. & $7 / 22 / 1993$ & & Emission standard violation \\
\hline 5300 & Lotte Chilsung Beverage Co. & $7 / 29 / 1999$ & & Emission standard violation \\
\hline 5420 & Hankook Titanium Industry & 2/6/1992 & & Emission standard violation \\
\hline 5490 & Pohang Iron \& Steel Co. & & $11 / 30 / 1996$ & Failure to operate PCE properly \\
\hline 5600 & Joongang Paper & & 9/27/1993 & Emission standard violation \\
\hline 5740 & Crown Confectionary Co. & & $11 / 3 / 1999$ & Emission standard violation \\
\hline 5810 & Pungsan & & 9/27/1993 & Emission standard violation \\
\hline 5810 & Pungsan & & $7 / 30 / 1996$ & Failure to operate PCE properly \\
\hline 5950 & Isuchemical Co. & $7 / 20 / 1999$ & & Emission standard violation \\
\hline 6040 & Dongwon Industries Co. & & 3/4/1999 & Emission standard violation \\
\hline 6070 & Kirin & $3 / 11 / 1993$ & & Use of equipment without government permission \\
\hline 6390 & Hyundai Cement Industrial & & $4 / 27 / 1993$ & Failure to operate PCE properly \\
\hline 6390 & Hyundai Cement Industrial & $10 / 28 / 1996$ & & Emission standard violation \\
\hline 6390 & Hyundai Cement Industrial & & $12 / 30 / 1996$ & Emission standard violation \\
\hline 6400 & Samsung SDI Co. & $8 / 22 / 1996$ & & Emission standard violation \\
\hline 7410 & Daewoo Electronics Co. & 8/28/1994 & & Emission standard violation \\
\hline 7410 & Daewoo Electronics Co. & $8 / 31 / 1996$ & & Emission standard violation \\
\hline 7810 & Korea Cerkit & $10 / 1 / 1994$ & & Failure to operate PCE properly \\
\hline 8720 & Samyang Heavy Machinery Co. & $11 / 30 / 1993$ & & Failure to operate PCE properly \\
\hline 8900 & SBW Co. & $6 / 23 / 1993$ & & Emission standard violation \\
\hline 8900 & SBW Co. & $12 / 25 / 1994$ & & Emission standard violation \\
\hline 8970 & Dongyangcheolgwan & $1 / 26 / 1994$ & & Failure to operate PCE properly \\
\hline 9580 & Donghae Pulp Co. & & $7 / 1 / 1994$ & Emission standard violation \\
\hline 9840 & Kabool Co. & $3 / 1 / 1994$ & & Emission standard violation \\
\hline 9840 & Kabool Co. & 3/30/1994 & & Emission standard violation \\
\hline 9840 & Kabool Co. & $4 / 27 / 1994$ & & Emission standard violation \\
\hline 10140 & Samsung Heavy Industries Co. & $12 / 25 / 1994$ & & Failure to operate PCE properly \\
\hline 10780 & Dongseo Industrial & 7/1/1994 & & Failure to operate PCE properly \\
\hline 10780 & Dongseo Industrial & & 12/1/1999 & Emission standard violation \\
\hline 11780 & Kumho Petrochemical Co. & $7 / 6 / 1996$ & & Emission standard violation \\
\hline 14580 & Bakgwang Material & $12 / 28 / 1999$ & & Emission standard violation \\
\hline 15760 & Korea Electric Power Corporation & $7 / 29 / 1999$ & & Use of equipment without government permission \\
\hline 15760 & Korea Electric Power Corporation & 8/27/1999 & & Emission standard violation \\
\hline 16380 & Dongbu Steel Co. & $8 / 31 / 1996$ & & Emission standard violation \\
\hline 16380 & Dongbu Steel Co. & 6/30/1999 & & Polluting water resource \\
\hline 16380 & Dongbu Steel Co. & & $8 / 27 / 1999$ & Polluting water resource \\
\hline 23150 & Muhak Jujeong & & $1 / 31 / 2000$ & Emission standard violation \\
\hline 25830 & Hankook Synthetic Fiber & $8 / 31 / 1996$ & & Emission standard violation \\
\hline 25860 & Namhae Chemical & & $11 / 30 / 1996$ & Failure to operate PCE properly \\
\hline
\end{tabular}




\section{Appendix 3 \\ Market reaction to news ${ }^{1}$}

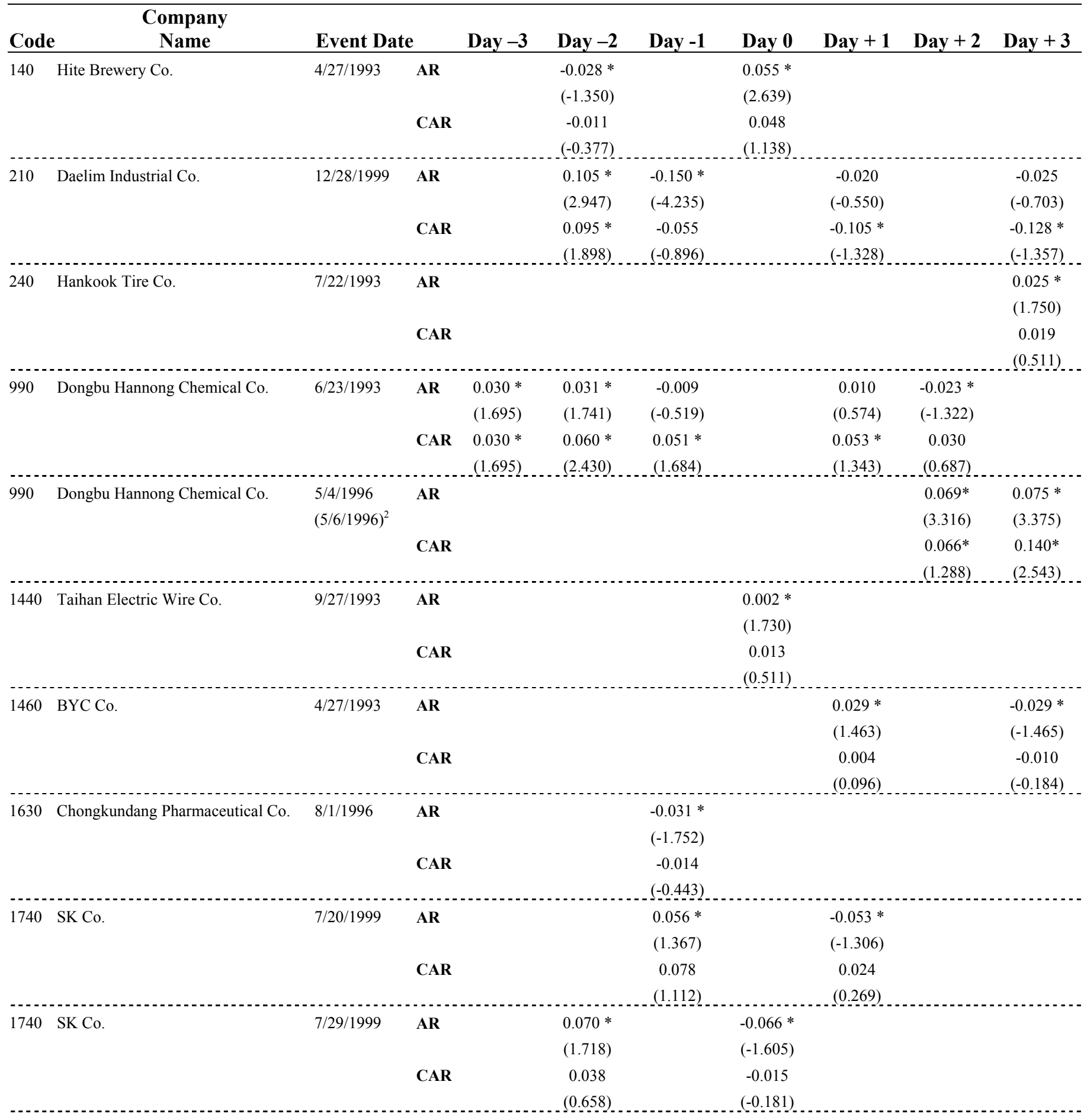




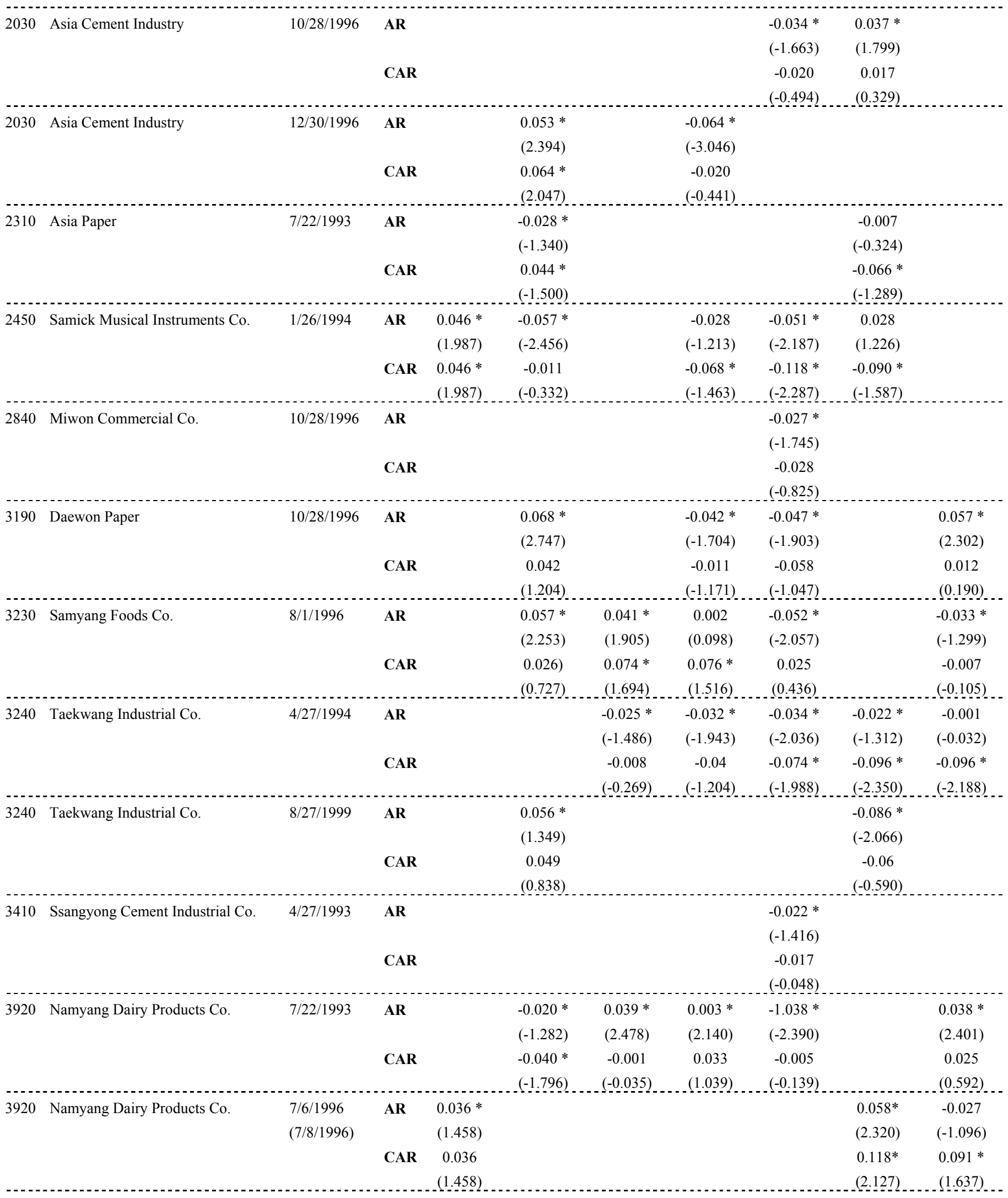




\begin{tabular}{|c|c|c|c|c|c|c|c|c|c|c|}
\hline \multirow[t]{2}{*}{3980} & Hanil Synthetic Fiber Co. & $4 / 27 / 1994$ & $\mathbf{A R}$ & $\begin{array}{l}-0.049 * \\
(-1.644)\end{array}$ & $\begin{array}{c}-0.022 \\
(-0.738)\end{array}$ & $\begin{array}{c}0.005 \\
(0.151)\end{array}$ & $\begin{array}{c}-0.030 \\
(-0.991)\end{array}$ & $\begin{array}{l}-0.057 * \\
(-1.887)\end{array}$ & $\begin{array}{l}0.054 * \\
(1.784)\end{array}$ & $\begin{array}{l}-0.039 * \\
(-1.326)\end{array}$ \\
\hline & & & CAR & $-0.049 *$ & $-0.071 *$ & $-0.067 *$ & $-0.097 *$ & $-0.153 *$ & $-0.100 *$ & $-0.140 *$ \\
\hline \multirow[t]{2}{*}{4370} & Nong Shim Co. & 9/27/1993 & $\mathbf{A R}$ & & & $0.018 *$ & & & & \\
\hline & & & & & & $(1.328)$ & & & & \\
\hline \multirow[t]{4}{*}{4460} & Kohap Co. & $4 / 27 / 1993$ & $\mathbf{A R}$ & & $-0.026 *$ & & & & & \\
\hline & & & & & $(-1.554)$ & & & & & \\
\hline & & & CAR & & $-0.032 *$ & & & & & \\
\hline & & & & & $(-1.360)$ & & & & & \\
\hline 5070 & Saehan Media Co. & 8/1/1996 & $\mathbf{A R}$ & & & & $-0.030 *$ & & & \\
\hline \multirow[t]{4}{*}{5300} & Lotte Chilsung Beverage Co. & 7/22/1993 & $\mathbf{A R}$ & $-0.025 *$ & $0.038 *$ & & & & & \\
\hline & & & & $(-1.471)$ & $(2.221)$ & & & & & \\
\hline & & & CAR & $-0.025 *$ & 0.013 & & & & & \\
\hline & & & & $(-1.471)$ & $(0.530)$ & & & & & \\
\hline \multirow[t]{4}{*}{5300} & Lotte Chilsung Beverage Co. & $7 / 29 / 1999$ & $\mathbf{A R}$ & $-0.055^{*}$ & -0.015 & -0.012 & -0.039 & -0.003 & $-0.062 *$ & 0.024 \\
\hline & & & & $(-1.687)$ & $(-0.460)$ & $(-0.357)$ & $(-1.188)$ & $(-0.101)$ & $(-1.898)$ & $(0.731)$ \\
\hline & & & CAR & $-0.055 *$ & $-0.070 *$ & $-0.082 *$ & $-0.121 *$ & $-0.124 *$ & $-0.186 *$ & $-0.162 *$ \\
\hline & $\ldots$ & & $\ldots . .$. & $(-1.687)$ & $(-1.518)$ & $(-1.445)$ & $(-1.846)$ & $(-1.697)$ & $(-2.323)$ & $(-1.875)$ \\
\hline \multirow[t]{2}{*}{5420} & Hankook Titanium Industry & $2 / 6 / 1992$ & $\mathbf{A R}$ & & & $0.036 *$ & $-0.044 *$ & & & $0.037 *$ \\
\hline & & & & & & $(1.360)$ & $(-1.648)$ & & & $(1.384)$ \\
\hline \multirow[t]{4}{*}{6070} & Kirin & $3 / 11 / 1993$ & $\mathbf{A R}$ & & & & & & & $0.037 *$ \\
\hline & & & & & & & & & & $(1.359)$ \\
\hline & & & CAR & & & & & & & 0.063 \\
\hline & & & & & & & & & & $(0.869)$ \\
\hline \multirow[t]{4}{*}{6390} & Hyundai Cement Industrial & $10 / 28 / 1996$ & $\mathbf{A R}$ & & & & & & $0.052 *$ & \\
\hline & & & & & & & & & $(2.507)$ & \\
\hline & & & CAR & & & & & & $0.060 *$ & \\
\hline & & & & & & & & & $(1.183)$ & \\
\hline \multirow[t]{4}{*}{6400} & Samsung SDI Co. & $8 / 22 / 1996$ & $\mathbf{A R}$ & & & & & $-0.017 *$ & $-0.023 *$ & -0.006 \\
\hline & & & & & & & & $(-1.316)$ & $(-1.766)$ & $(-0.440)$ \\
\hline & & & CAR & & & & & $-0.039 *$ & $-0.062 *$ & $-0.068 *$ \\
\hline & & & & & & & & $(-1.316)$ & $(-1.923)$ & $(-1.949)$ \\
\hline \multirow[t]{3}{*}{7410} & Daewoo Electronics Co. & $8 / 28 / 1994$ & $\mathbf{A R}$ & & & $-0.030 *$ & & & $-0.027 *$ & \\
\hline & & $(8 / 29 / 1996)$ & & & & $(-1.541)$ & & & $(-1.366)$ & \\
\hline & & & CAR & & & -0.016 & & & -0.054 & \\
\hline
\end{tabular}




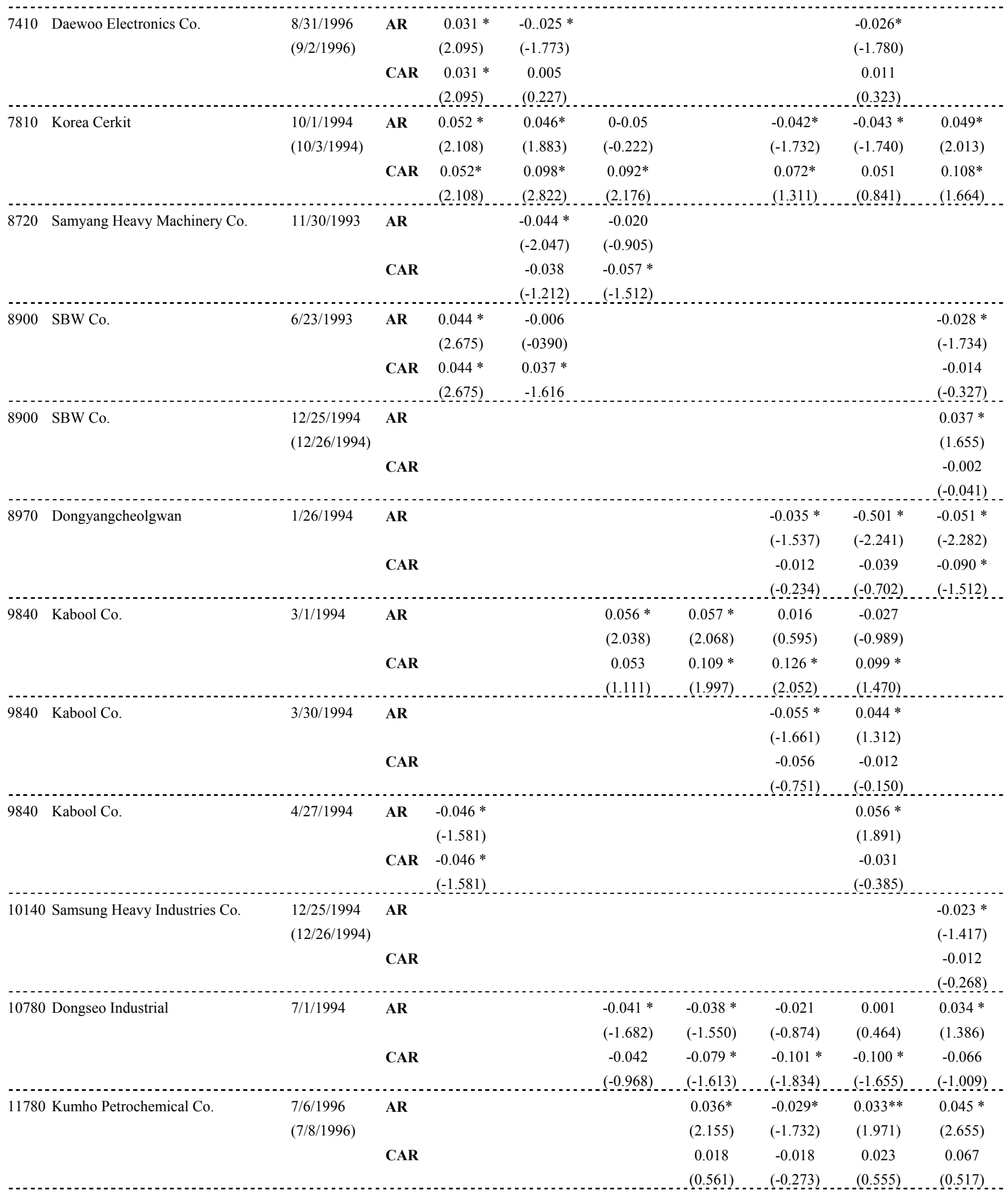




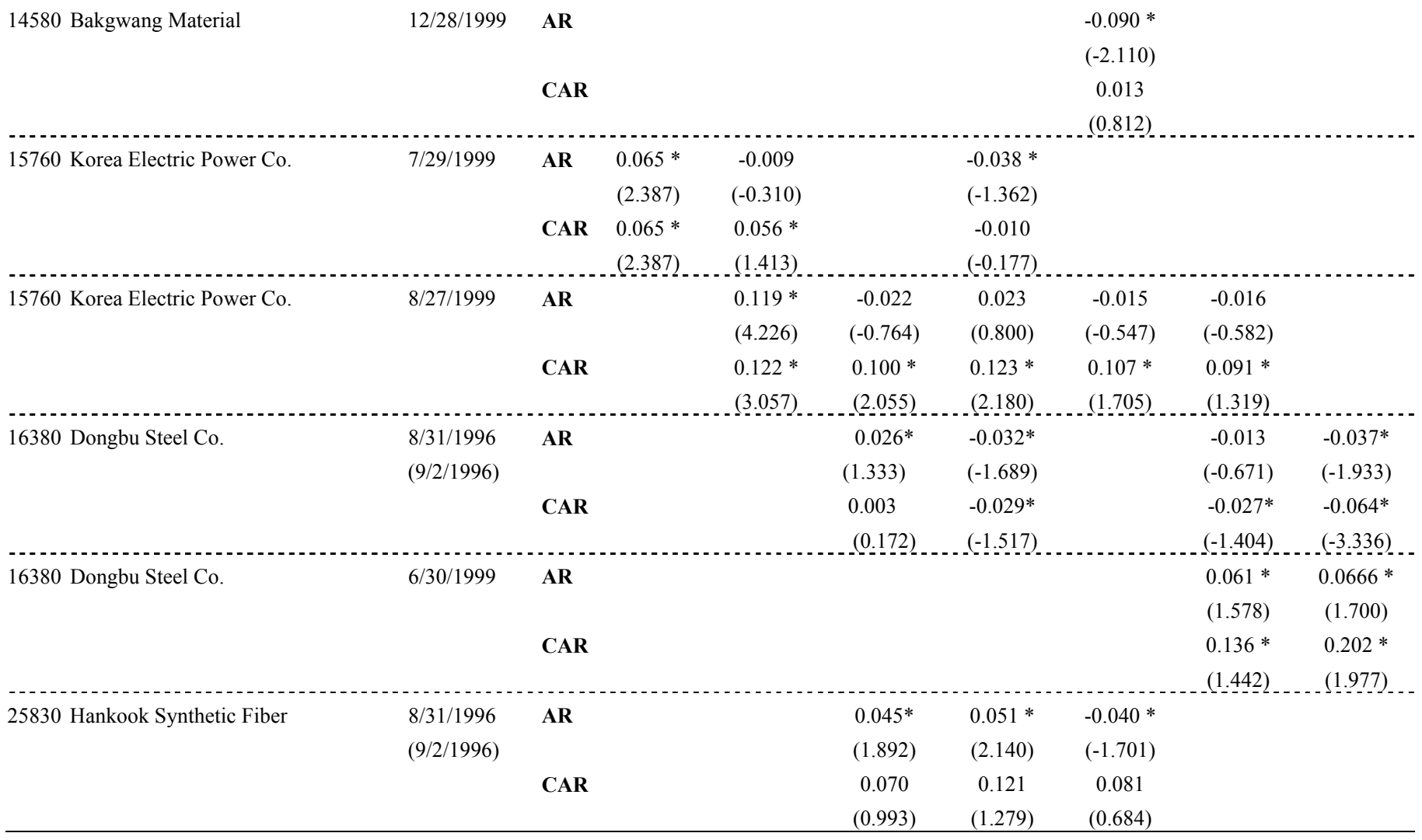

${ }^{1} \mathbf{A R}$ stands for abnormal return and $\mathbf{C A R}$ is the cumulative abnormal return. CAR is computed for Day -3 up to the specified day of interest. Within brackets is the value of $\mathrm{z}$ statistics. '*' denotes significance at the $10 \%$ level (two tailed test). If an event had no statistically significant AR for any of the days over the period of the even window ( -3 to +3$)$, then that event was not retained as statistically significant even if some of its CAR may have been statistically significant. On the other hand, if an event has at least one statistically significant $\mathbf{A R}$ during the event window, then all statistically significant results are reported for that event, even on those days where only the CAR is statistically significant.

${ }^{2}$ A number of events appears in newspapers on days where the stock market is close (Saturdays, Sundays, or public holidays). In such circumstances, the immediate following day of trading (as indicated by the date in bracket) is used as day 0 . 
Appendix 4

Market reaction and media coverage

\begin{tabular}{|c|c|c|c|c|}
\hline Code & Company Name & Reaction & No Reaction & $\begin{array}{c}\text { Number of newspapers that have } \\
\text { covered this event }\end{array}$ \\
\hline 80 & Jinro & & $5 / 31 / 1994$ & 2 \\
\hline 140 & Hite Brewery Co. & $4 / 27 / 1993$ & & 3 \\
\hline 210 & Daelim Industrial Co. & & $7 / 22 / 1993$ & 3 \\
\hline 210 & Daelim Industrial Co. & $12 / 28 / 1999$ & & 1 \\
\hline 240 & Hankook Tire Co. & $7 / 22 / 1993$ & & 3 \\
\hline 240 & Hankook Tire Co. & & $7 / 6 / 1996$ & 2 \\
\hline 240 & Hankook Tire Co. & & $8 / 26 / 1999$ & 1 \\
\hline 270 & Kia Motors & & $8 / 26 / 1999$ & 1 \\
\hline 990 & Dongbu Hannong Chemical Co. & $6 / 23 / 1993$ & & 1 \\
\hline 990 & Dongbu Hannong Chemical Co. & & $4 / 28 / 1994$ & 3 \\
\hline 990 & Dongbu Hannong Chemical Co. & $5 / 4 / 1996$ & & 2 \\
\hline 1390 & Gyeonggi Chemical & & $8 / 28 / 1994$ & 3 \\
\hline 1390 & Gyeonggi Chemical & & $8 / 31 / 1996$ & 1 \\
\hline 1430 & Kia Steel Co. & & $8 / 27 / 1993$ & 3 \\
\hline 1430 & Kia Steel Co. & & $12 / 29 / 1996$ & 1 \\
\hline 1440 & Taihan Electric Wire Co. & 9/27/1993 & & 1 \\
\hline 1460 & BYC Co. & $4 / 27 / 1993$ & & 2 \\
\hline 1630 & Chongkundang Pharmaceutical Co. & $8 / 1 / 1996$ & & 2 \\
\hline 1740 & SK Co. & $7 / 20 / 1999$ & & 1 \\
\hline 1740 & SK Co. & $7 / 29 / 1999$ & & 1 \\
\hline 2030 & Asia Cement Industry & & $8 / 28 / 1994$ & 3 \\
\hline 2030 & Asia Cement Industry & $10 / 28 / 1996$ & & 2 \\
\hline 2030 & Asia Cement Industry & $12 / 30 / 1996$ & & 5 \\
\hline 2170 & Samyang Tongsang Co. & & $4 / 3 / 1993$ & 1 \\
\hline 2270 & Lotte samkang Co. & & $1 / 20 / 2000$ & 4 \\
\hline 2310 & Asia Paper & $7 / 22 / 1993$ & & 3 \\
\hline 2450 & Samick Musical Instruments Co. & $1 / 26 / 1994$ & & 3 \\
\hline 2840 & Miwon Commercial Co. & $10 / 28 / 1996$ & & 2 \\
\hline 3190 & Daewon Paper & & $9 / 27 / 1993$ & 1 \\
\hline 3190 & Daewon Paper & $10 / 28 / 1996$ & & 1 \\
\hline 3230 & Samyang Foods Co. & & $4 / 4 / 1993$ & 4 \\
\hline 3230 & Samyang Foods Co. & $8 / 1 / 1996$ & & 1 \\
\hline 3240 & Taekwang Industrial Co. & $4 / 27 / 1994$ & & 2 \\
\hline 3240 & Taekwang Industrial Co. & 8/27/1999 & & 1 \\
\hline 3410 & Ssangyong Cement Industrial Co. & $4 / 27 / 1993$ & & 1 \\
\hline 3920 & Namyang Dairy Products Co. & $7 / 22 / 1993$ & & 5 \\
\hline 3920 & Namyang Dairy Products Co. & $7 / 6 / 1996$ & & 1 \\
\hline 3980 & Hanil Synthetic Fiber Co. & $4 / 27 / 1994$ & & 2 \\
\hline 3980 & Hanil Synthetic Fiber Co. & & $5 / 31 / 1994$ & 1 \\
\hline 4370 & Nong Shim Co. & $9 / 27 / 1993$ & & 2 \\
\hline 4460 & Kohap Co. & $4 / 27 / 1993$ & & 4 \\
\hline 4460 & Kohap Co. & & $6 / 24 / 1993$ & 4 \\
\hline 4690 & Samchully Co. & & $4 / 3 / 1993$ & 1 \\
\hline 4980 & Sungshin Cement Mfq. Co. & & $10 / 28 / 1996$ & 1 \\
\hline 5070 & Saehan Media Co. & & 4/3/1993 & 1 \\
\hline 5070 & Saehan Media Co. & & $8 / 27 / 1993$ & 2 \\
\hline
\end{tabular}




\begin{tabular}{|c|c|c|c|c|}
\hline 5070 & Saehan Media Co. & 8/1/1996 & & 1 \\
\hline 5180 & Binggrae & & $1 / 31 / 2000$ & 1 \\
\hline 5300 & Lotte Chilsung Beverage Co. & $7 / 22 / 1993$ & & 6 \\
\hline 5300 & Lotte Chilsung Beverage Co. & $7 / 29 / 1999$ & & 1 \\
\hline 5420 & Hankook Titanium Industry & $2 / 6 / 1993$ & & 1 \\
\hline 5490 & Pohang Iron \& Steel Co. & & $11 / 30 / 1996$ & 1 \\
\hline 5600 & Joongang Paper & & 9/27/1993 & 1 \\
\hline 5740 & Crown Confectionary Co. & & $11 / 3 / 1999$ & 1 \\
\hline 5810 & Pungsan & & 9/27/1993 & 2 \\
\hline 5810 & Pungsan & & $7 / 30 / 1996$ & 1 \\
\hline 5950 & Isuchemical Co. & $7 / 20 / 1999$ & & 1 \\
\hline 6040 & Dongwon Industries Co. & & $3 / 4 / 1999$ & 1 \\
\hline 6070 & Kirin & $3 / 11 / 1993$ & & 1 \\
\hline 6390 & Hyundai Cement Industrial & & $4 / 27 / 1993$ & 1 \\
\hline 6390 & Hyundai Cement Industrial & $10 / 28 / 1996$ & & 3 \\
\hline 6390 & Hyundai Cement Industrial & & $12 / 30 / 1996$ & 3 \\
\hline 6400 & Samsung SDI Co. & $8 / 22 / 1996$ & & 1 \\
\hline 7410 & Daewoo Electronics Co. & $8 / 28 / 1994$ & & 3 \\
\hline 7410 & Daewoo Electronics Co. & $8 / 31 / 1996$ & & 1 \\
\hline 7810 & Korea Cerkit & 10/1/1994 & & 2 \\
\hline 8720 & Samyang Heavy Machinery Co. & $11 / 30 / 1993$ & & 1 \\
\hline 8900 & SBW Co. & $6 / 23 / 1993$ & & 1 \\
\hline 8900 & SBW Co. & $12 / 25 / 1994$ & & 1 \\
\hline 8970 & Dongyangcheolgwan & $1 / 26 / 1994$ & & 2 \\
\hline 9580 & Donghae Pulp Co. & & $7 / 1 / 1994$ & 2 \\
\hline 9840 & Kabool Co. & 3/1/1994 & & 1 \\
\hline 9840 & Kabool Co. & $3 / 30 / 1994$ & & 3 \\
\hline 9840 & Kabool Co. & $4 / 27 / 1994$ & & 1 \\
\hline 10140 & Samsung Heavy Industries Co. & $12 / 25 / 1994$ & & 2 \\
\hline 10780 & Dongseo Industrial & 7/1/1994 & & 1 \\
\hline 10780 & Dongseo Industrial & & $12 / 1 / 1999$ & 1 \\
\hline 11780 & Kumho Petrochemical Co. & $7 / 6 / 1996$ & & 2 \\
\hline 14580 & Bakgwang Material & $12 / 28 / 1999$ & & 1 \\
\hline 15760 & Korea Electric Power Corporation & $7 / 29 / 1999$ & & 1 \\
\hline 15760 & Korea Electric Power Corporation & $8 / 27 / 1999$ & & 1 \\
\hline 16380 & Dongbu Steel Co. & $8 / 31 / 1996$ & & 2 \\
\hline 16380 & Dongbu Steel Co. & 6/30/1999 & & 2 \\
\hline 16380 & Dongbu Steel Co. & & $8 / 27 / 1999$ & 1 \\
\hline 23150 & Muhak Jujeong & & $1 / 31 / 2000$ & 1 \\
\hline 25830 & Hankook Synthetic Fiber & $8 / 31 / 1996$ & & 1 \\
\hline 25860 & Namhae Chemical & & $11 / 30 / 1996$ & 2 \\
\hline
\end{tabular}




\section{Annex 5 \\ Testing for differences in changes in market value: Violation of emission standard vs. Failure to operate PCE properly}

The null hypothesis is $H_{0}: \mu_{2}=\mu_{3}$ or $\mu_{2}-\mu_{3}=0$ and the alternative is $H_{1}: \mu_{2} \neq \mu_{3}$ or $\mu_{2}-\mu_{3} \neq 0$ where the $\mu^{\prime} s$ are the respective population means: $\mu_{2}$ mean reduction for population corresponding to emission standards violation and $\mu_{3}$ is that for population corresponding to failure to operate PCE properly. The sample means can be defined similarly: $X_{2}$ and $X_{3}$. Since both samples are small (27 stocks with negative reaction and 7 stocks with negative events), we recourse to t-test statistic. It is computed as follows:

$$
t=\frac{\left(\bar{X}_{2}-\bar{X}_{3}\right)-\left(\mu_{2}-\mu_{3}\right)}{S_{p} \sqrt{\frac{1}{n_{2}}+\frac{1}{n_{3}}}} \sim t_{n_{2}+n_{3}-2}
$$

where $S_{p}^{2}=\frac{\left(n_{2}-1\right) S_{2}^{2}+\left(n_{3}-1\right) S_{3}^{2}}{\left(n_{2}+n_{3}-2\right)}$ is the pooled variance, $S_{2}^{2}$ and $S_{3}^{2}$ are the variance of stocks with negative reactions corresponding to emission standard violation and failure to operate PCE properly, respectively, and the $n_{2}$ and $n_{3}$ are the number of stocks with negative reactions in each category.

Applying the t-formula above yields:

$$
t=\frac{-0.0896+0.153-0}{0.055921}=1.134
$$

Since $t<t_{32,0.05} \approx 1.697$, we accept the null hypothesis at the $10 \%$ level of significance that there is no significant difference between negative market reaction from events of violation of emission standards and that of events of failure to operate PCE. 


\section{Annex 6 \\ Testing for differences in changes in market value: Changes over time}

The null hypothesis is $H_{0}: \mu_{4}=\mu_{5}=\mu_{6}$ and the alternative is $H_{1}: \mu_{4} \neq \mu_{5} \neq \mu_{6} \quad$ where the $\mu^{\prime} s$ are the respective population means. We have the comparison of more than two means. Here the use of the $\mathrm{t}$ test statistic is not appropriate (see Ott and Longnecker (2001)). We recourse to the analysis of variance to solve the problem of size distortion that may entail the use of t. Precisely, we build an F-test statistic:

$$
F=\frac{S_{B}^{2}}{S_{W}^{2}} \sim F_{n-s}^{s}
$$

where $S_{B}^{2}$ and $S_{W}^{2}$ are the between-sample variance(mean square) and the within-sample variance (mean square), respectively. Precisely, $S_{B}^{2}=\frac{\sum_{i=1}^{s} n_{i}\left(\bar{X}_{i}-\bar{X}\right)}{s-1}$ where s stands for the total number of samples and the $\mathrm{X}$ bars are the means for a given sample $i$ or the grand mean. The within variance is an extension of the pooled variance developed above. Using the data, the $\mathrm{F}$ value is:

$$
F=\frac{0.0343310}{0.011227972}=3.058
$$

Since $F>F_{36}^{2} \approx 2.44$ at the $10 \%$ level of significance, we reject the null hypothesis and conclude that the average $\%$ reduction in stock market is changing over time. 


\section{Annex 7 \\ Testing for differences in changes in market value: \\ Extent of coverage by newspapers}

We break down this test into two different sub-tests.

$\underline{\text { Sub-test } 1}$. Is there any difference in \% reduction in stock market values between events that are covered only in 1 or 2 in newspapers vs. those events that are covered in $3,4,5$, or 6 newspapers.

The null hypothesis is $H_{0}: \mu_{7}=\mu_{8}$ or $\mu_{7}-\mu_{8}=0$ the alternative is $H_{1}: \quad \mu_{7} \neq \mu_{8} \quad$ where the $\mu^{\prime} s$ are the respective population means. Using the t-test statistic as presented in Appendix 5, we obtain:

$$
t=\frac{-0.0446+0.161-0}{0.055844733}=2.084
$$

Since $2.084>1.645$ at the $10 \%$ level of significance, we reject the null hypothesis and conclude that the number of coverage matters in market reaction.

$\underline{\text { Sub-test } 2}$. Is there any difference in \% reduction in stock market values between events that are covered only in 1 or 2 in newspapers vs. those events that are covered in 5,6 newspapers.

The null hypothesis is $H_{0}: \mu_{7}=\mu_{9}$ or $\mu_{7}-\mu_{9}=0$ the alternative is $H_{1}: \quad \mu_{7} \neq \mu_{9} \quad$ where the $\mu^{\prime} s$ are the respective population means (equivalent of table 7 and Table 9, respectively). Using the similar t-test statistic, we obtain:

$$
t=\frac{-0.0446+0.3823-0}{0.094617367}=3.554
$$


Since $3.554>\mathrm{t}(29,0.10)=1.699$ at the $10 \%$ level of significance, we reject the null hypothesis and conclude that the number of coverage matters in market reaction. 